\title{
Seasonal variation in community structure and recruitment of benthic decapods in a sub-tidal cobble habitat
}

\author{
Martin Robinson*, Oliver Tully \\ Department of Zoology, Trinity College, Dublin, Ireland
}

\begin{abstract}
Quantitative suction samples of benthic decapod fauna were taken in the south of Ireland during 1997. Some species settled into the area, but failed to persist to the first winter, while others were present in high numbers throughout the year. The duration of settlement was speciesspecific, ranging from several weeks to several months. Body size at settlement decreased with increasing temperature during larval development. Growth potential and early mortality of a number of decapod species was examined by separation of successive moult instars from length-frequency distributions. Seasonal lows in abundance and biomass of young of the year and for previously established decapod individuals were identified at the end of July and early August, which may represent the most suitable time to release juveniles for stock-enhancement purposes. Community structure differed between settlement season and over-wintering periods. Young-of-the-year community structure differed from that of previously established individuals, with higher abundance and number of species recorded for the former. The data represent a baseline study of a widely distributed community and may support further work on species interactions, improving the accuracy of prediction of annual recruitment fluctuations.
\end{abstract}

KEY WORDS: Community · Decapod $\cdot$ Recruitment $\cdot$ Seasonal variation

\section{INTRODUCTION}

Sub-tidal cobble habitats often support dense, species-rich marine communities and decapod crustaceans can comprise a major component of the overall species abundance and biomass within such communities. Some species settle into (and remain within) shallow physically complex substrata, while others undergo a subsequent ontogenetic shift at a later stage of development (Cobb \& Wahle 1994, Perkins-Visser et al. 1996, Pile et al. 1996, Moksnes et al. 1998). The importance of nursery habitats in the survival and development of decapod species has been well documented (Wahle \& Steneck 1992, Eggleston \& Arm-

${ }^{*}$ E-mail: robinsom@tcd.ie strong 1995, Pile et al. 1996). When the species is of commercial value, the success of the fishery may well depend on recruitment from such areas.

Physical (Eckman 1983, Hobbs et al. 1992, Eggleston \& Armstrong 1995, Wahle \& Incze 1997) and biotic (Olmi \& Lipcius 1991, Eggleston \& Armstrong 1995) processes affect pre- and post-settlement processes, and influence subsequent recruitment (Phillips 1990, Pile et al. 1996). Cohort strength and subsequent population size in these species may therefore be determined early in their life history (Pile et al. 1996). Studies of these critical life-history phases can therefore greatly increase the understanding of population rateprocesses such as settlement, recruitment, post-settlement growth and mortality, and density-dependant control of these processes. Gosselin \& Qian (1997) list numerous studies of marine invertebrates in which 
population abundance, distribution and community structure are controlled or influenced by juvenile mortality. Mortality and displacement quickly shape the resultant community structure of the species within the habitat.

Initial mortality rates (Connell \& Jones 1991) of early benthic stages are generally accepted as being very high. Both physical (Roughgarden et al. 1988, White et al. 1988, McConnaughey et al. 1992, Young et al. 1998) and biological (Phillips 1990, Olmi \& Lipcius 1991, Eggleston \& Armstrong 1995, Pile et al. 1996) factors contribute to inter-annual and within-season recruitment variability. At temperate latitudes, the conditions encountered by developing larvae can differ markedly over time. Inequalities in the magnitude of settlement and subsequent survival of settlers during the settlement season can lead to short-term variability in the abundance of the young-of-the-year (YOY) cohort (Robinson \& Tully 2000a). The causes and magnitude of inter-annual variation in settlement and recruitment success has received increasing attention recently with the development of stock-prediction models for fisheries management. Attempts have been made to relate levels of larval supply, settlement and subsequent recruitment to the standing stock of the fishable adult population after application of a suitable lag phase. Advances have been made in the development of such recruitment indices and of forecasting methods for the Australian rock lobster Panulirus cygnus George (Phillips \& Brown 1989) and the American lobster Homarus americanus Milne Edwards (Incze \& Wahle 1991). Examination of seasonal settlement and recruitment can identify the most suitable time to conduct censuses of recruitment to form annual predictions. Identifying the most influential species or the biological or physical factor interacting with the target species and accounting for variability in their recruitment success, will enhance the accuracy of annual predictions. For example, recruitment of an exploited species within a year may be average, while recruitment of a predator species may be exceptionally high. Censuses of the fished cohort in the following year may then reveal unexpectedly high mortality.

There is a need for detailed knowledge of larval supply processes and dynamics, and of the post-settlement processes that act on decapod post-larval population until recruitment and subsequent benthic production occurs, in order to understand the adult-recruit relationship in closed populations and density-dependant constraints in early life history. Decapod assemblages similar to the one examined in this study, and dominated by Pisidia longicornis (L.), are resident in subtidal cobble habitats to depths of $50+\mathrm{m}$ throughout much of the eastern north Atlantic (Smaldon 1972, González-Sanjurjo 1982). This study is the first to re- port on the community structure, recruitment and early post-settlement growth and mortality in this decapod assemblage. Seasonal variation in YOY community statistics and community structure are examined and related to the established decapod community.

\section{MATERIALS AND METHODS}

Samples were collected randomly from an area with uniform habitat characteristics within the Saltees Sound, County Wexford, Ireland (Fig. 1). Sampling was conducted on a monthly basis between December 1996 and November 1997, with the exception of February and October, when poor weather conditions prevented collections. Sampling was conducted more frequently between June and September, since newly settled YOY were detected during this period. The exact frequency and timing of each sampling effort at this relatively exposed site was often determined by sea conditions. The substratum in the area consisted of gravel and shell, overlain by boulders and cobble of various sizes (Robinson \& Tully 2000b). The finer sediment and interstitial spacing between the cobbles afforded shelter to numerous decapod species. Due to the perennial nature of the Laminaria species present, algal cover varied throughout the year, but was estimated by divers as being typically between 50 and $70 \%$ during the settlement season. Sampling was conducted at a depth of 8 to $10 \mathrm{~m}$. Temperature was monitored at $2 \mathrm{~h}$ intervals by a Seamon ${ }^{\circledR}$ temperature recorder deployed near the seabed.

SCUBA divers randomly positioned $0.5 \times 0.5 \mathrm{~m}$ quadrats on the seabed. The area contained within each quadrat was sampled in situ using a diver-operated suction sampler. Air supply to the sampler was provided via a spare diving cylinder carried by the operator. In situ sampling permitted collection from sheltered lower surfaces and crevices of large rocks and boulders that support high densities of juvenile decapods. All fauna was collected in rigid $1 \mathrm{~mm}$ mesh bags.

In the laboratory, while submerged in seawater, the samples were sieved through progressively smaller mesh sizes down to $1.0 \mathrm{~mm}$. Individual decapods were fixed in $5 \%$ formalin containing $5 \%$ glycerol (to maintain flexibility). Maximum carapace width of large crabs $(>3.0 \mathrm{~mm})$ were recorded to the nearest $0.1 \mathrm{~mm}$ using digital callipers. Individuals $<3.0 \mathrm{~mm}$ were sized to the nearest $0.1 \mathrm{~mm}$ using a binocular microscope micrometer. Carapace length was recorded for Galathidea, uropod length and eye width for Caridea and shield length for Paguridea. The total wet weight of individuals was recorded using a Sartorius 3-point balance. 
The number of YOY specimens within each sample was estimated by construction of length-frequency histograms. The YOY cohort was easily distinguishable in these distributions when adequate numbers were sampled.

Between-sampling date differences in total decapod abundance, total decapod biomass, and number of decapod species present were examined using ANOVA. Post hoc tests revealed locations of significant seasonal variation. Analysis of abundance data was conducted separately for non-YOY and YOY components after ln transformation. High numbers of YOY individuals masked the abundance of non-YOY individuals. Multidimensional scaling ordination (MDS; Kruskal \& Wish 1978) was carried out using the computer package Primer $^{\odot}$ to examine seasonal variation in community structure in more detail. Only species that represented at least $4 \%$ of the overall species abundance at any sampling date were included in the analyses. Data was double-root transformed to reduce the influence of more dominant species. This transformation weighted the contribution of common and rare species so that the overall decapod assemblage could be compared between dates without a single species dominating the result. Simple removal of the most numerically dominant species before analysis would only serve to increase the influence of the next most numerically dominant species. The significance of differences in between-date Bray-Curtis similarities were tested using the ANOSIM routine (Clarke \& Warwick 1994). The program ANOSIM computes the average rank Bray-Curtis similarity between within-date samples and subtracts this from the average similarity between samples from different dates (Warwick et al. 1990). Significant seasonal variation is identified when replicates within a sampling date are more similar than replicates from other periods.

Within-sampling-date differences between the YOY and non-YOY community structures were examined using ANOSIM for simple species presence and absence data. The severe nature of the transformation removed the influence of the large differences between YOY and non-YOY abundances, allowing a direct comparison of the 2 components of the population. The component of the population referred to as non-YOY consisted of juvenile and mature adult individuals that had settled in previous years.

The mean body size of settlers was related to the average daily temperature for $30 \mathrm{~d}$ prior to settlement; $30 \mathrm{~d}$ was chosen as an arbitrary value for larval development of decapod species because of the poor availability of data for most species. Valdes \& Alverez Oso-

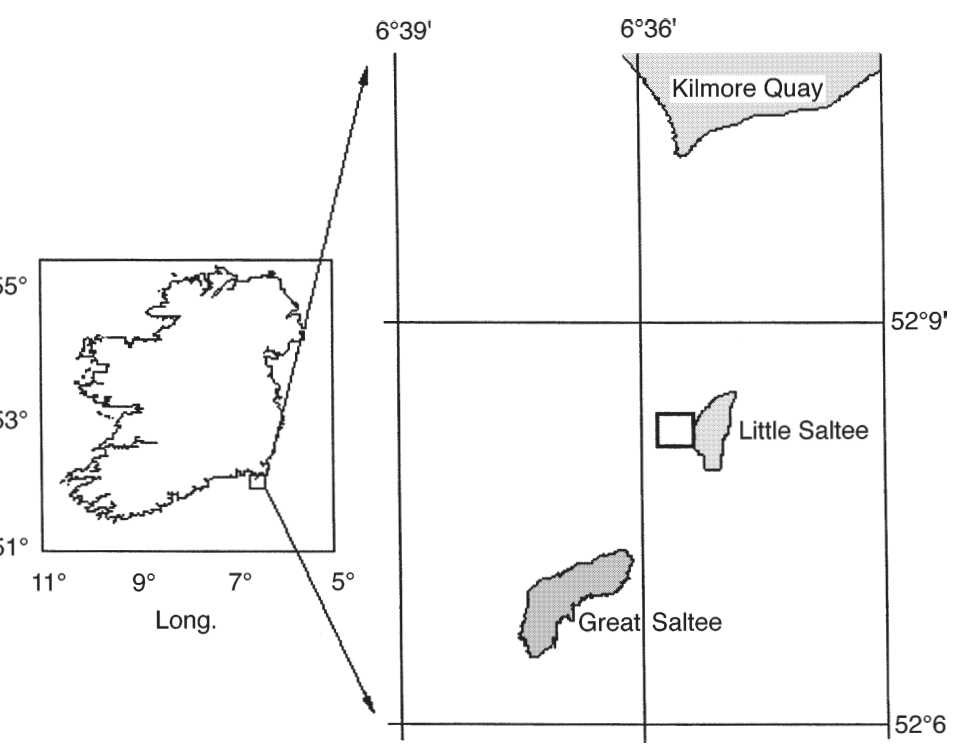

Fig. 1. Location of study site within Saltees Sound, Co. Wexford, reland. Black-rimmed square delimits approximate area of uniform substrate type within which random samples were taken

rio (1983) recorded a development time of $26 \mathrm{~d}$ at $15^{\circ} \mathrm{C}$ for Pisidia longicornis under laboratory conditions.

Seasonal growth estimates were derived for a number of species for which the YOY component was clearly identified. Growth potential was estimated by comparing minimum size at settlement and maximum size of individuals at the end of the growing season. Although the mean size at the start and end of the settlement season would be a more accurate assessment of growth potential, it was not always possible to separate successive instars from composite length-frequency distributions (LFD). As the environmental conditions during the year of study were typical for the south coast of Ireland, the growth range described was considered a reasonable approximation to the growth potential of individual species in this region.

Reductions in the total number of individuals sampled over the entire year between crab stages II and IV were taken to represent early seasonal mortality. Total abundances of YOY crab were used, as numbers collected in individual sampling dates were often too small to permit modal progression analysis. Separation of normal distributions and calculation of instar density was conducted using MIX 2.3 (MacDonald \& Green 1988). Castro (1995) found MIX (interactive program for fitting mixtures of distributions) to be a robust and efficient method for separation of mixtures of normal distributions after a comparison of numerous lengthfrequency techniques. The program separates normal distributions from composite length-frequency distributions by maximum likelihood estimation. Numbers of individuals within the first crab stage were omitted, as 


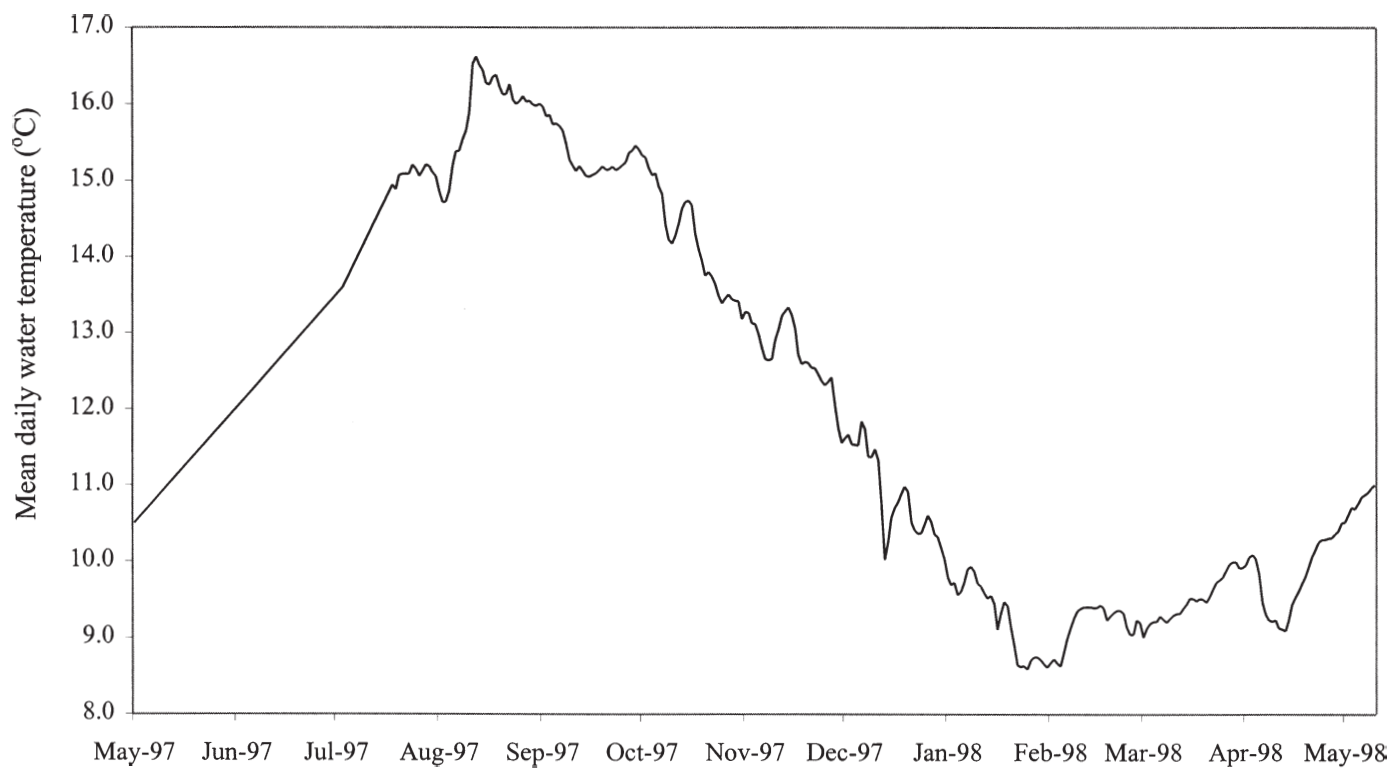

Fig. 2. Mean daily seawater temperature at $10 \mathrm{~m}$ depth calculated from 2-hourly recordings, from July 1997, in Saltees Sound, Co. Wexford. Data from May to July 1997 were estimated from single recordings taken in January and early July

it was not possible to predict the exact timing of the end of the settlement season. Further additions to this group could have occurred after sampling, especially for species that displayed intermittent pulsed settlement. Numbers of this first crab stage in the LFD often appeared to be far lower than would be expected when accounting for reduction of individuals between instars. This may indicate that settlement was often incomplete at sampling or that significant initial mortality had already occurred (Gosselin \& Qian 1997). Although a similar situation could be envisaged for later stages, as all individuals within settlement groups are unlikely to moult to the next stage in synchrony, estimates were thought to be less susceptible to bias than at the first crab stage. Abundance within instars after the first crab stage are dependant on the variability in the mortality of previously settled crabs, rather than on more large-scale variations associated with larval supply and settlement rate.

\section{RESULTS}

Average daily temperature at the site was calculated from the 12 daily recordings for the period July 1997 to May 1998 (Fig. 2). Although this did not coincide exactly with the duration of the study, it approximated the usual annual temperature regime of the area. Two sets of remote recordings were taken with a watertemperature meter, on 23 January $1997\left(8.0^{\circ} \mathrm{C}\right)$ and 8 July $1997\left(13.6^{\circ} \mathrm{C}\right)$, prior to the deployment of the probe. The highest mean daily temperature of $16.6^{\circ} \mathrm{C}$ was recorded in mid-August. July and September yielded comparable values of $15.0^{\circ} \mathrm{C}$. Temperature dropped significantly at the onset of October, reaching a minimum $\left(8.5^{\circ} \mathrm{C}\right)$ in early February. Increasing temperatures were recorded from mid-April onward. The water-temperature meter recordings in early January and July were used when estimating missing temperature values between May and late July by passing a straight line through these points.

During the study, 29 decapod species were recorded (Table 1). A number of species (indicated with an asterisk in Table 1) have not previously been described for this area (Healy \& McGrath 1988, Ingle 1993, 1996, Smaldon 1993, Kelly et al. 1996). The occurrence of species ranged from single observations of a lone individual, to high densities of individuals at all times. The small anomuran crab Pisidia longicornis was always highly abundant, representing $78 \%$ of the total number of individuals sampled during the entire study. There were differences in the overall mean abundance of species over the entire year $(p<0.001)$. However, high variation in numbers within sampling-date replicates led to only 3 significant between-date differences at the $5 \%$ level. Abundance was significantly higher in late August than in May, and greater in September than in both December and May. Numbers increased after the commencement of the main settlement season in June, and continued to rise until the approximate end of settlement in late September (Table 2). Numbers fell sharply between late September and November. Although the reduction in mean abundance of the non-YOY component of the assemblage over the year was noticeable, statistically sig- 
nificant differences existed only between April and early August, the seasonal maximum and minimum densities, respectively. The YOY densities in May and June, the start of the settlement season (Table 1), were significantly lower than on all other dates $(p<0.01)$. The mean abundance of individuals in early July was not significantly different ( $5 \%$ level) from that of late July and early August, but was significantly different from all subsequent dates. From late July onwards there was no significant difference in YOY abundance, but there was a trend towards increasing numbers until late September. Densities were noticeably lower in November. The proportion of the population constituted by the non-YOY component of the population was minimal in mid-August, when it represented only $20 \%$ of the community (Table 2).

There were no significant differences ( $5 \%$ level) in mean biomass between sampling dates. This was due mainly to the random occurrence of single large individuals in some samples, notably Cancer pagurus L., Necora puber (L.) and Xantho pilipes Milne Edwards. Within-sampling-date variation was reduced between June and early August, due to a reduction in the occurrence of such large individuals (Table 3 ). There was a distinct period between early July and late August when mean biomass was at its lowest (Table 3). The biomass of YOY individuals increased from the onset of the settlement season to the end of the study in November. Mean non-YOY biomass increased through August, but declined after the end of August until November. The proportion of the population biomass represented by YOY individuals was highest $(20 \%)$ in November. 


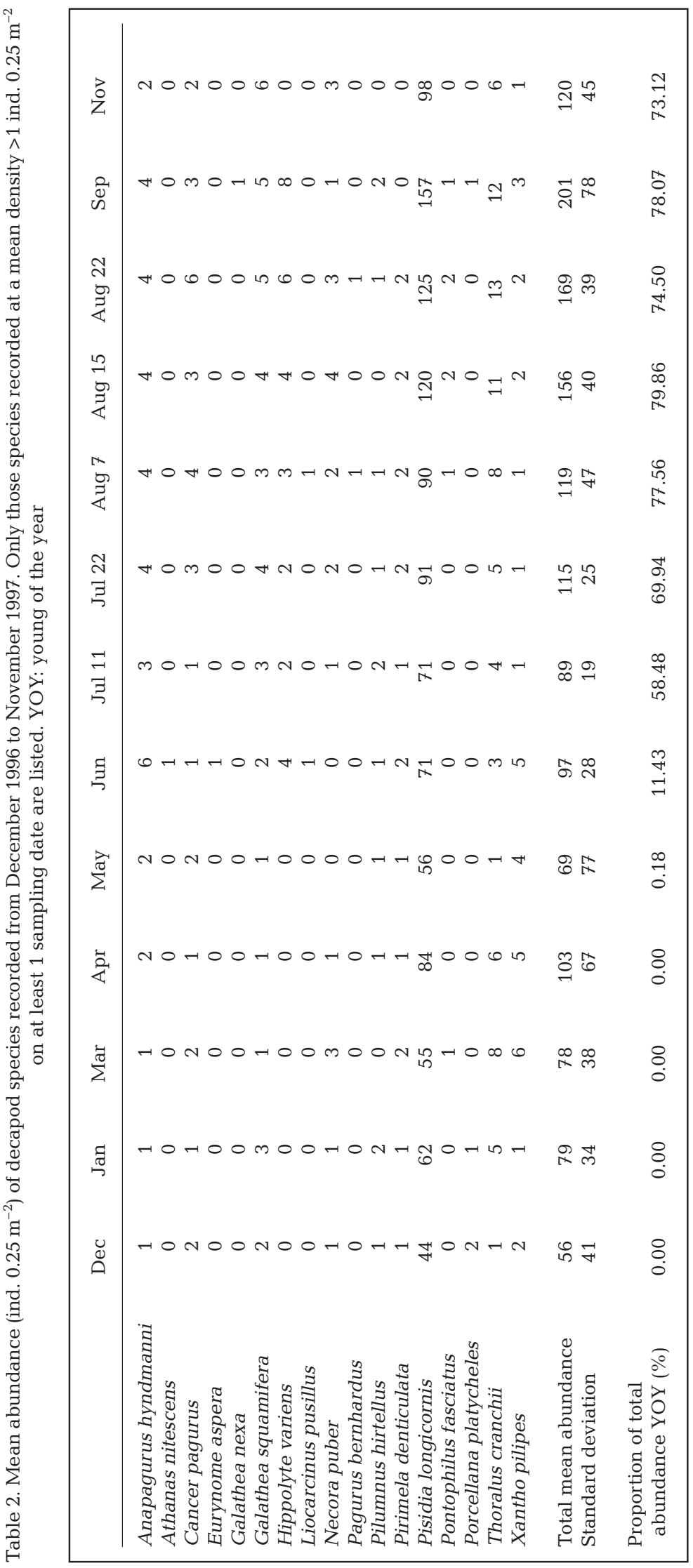

There was a general trend towards higher numbers of species during the settlement season. Significantly higher numbers of species (5\% level) occurred in the 4 samples between early August and September than in April and May. Some of the species, e.g. Liocarcinus pusilus (Leach) and Hippolyte variens Leach, which were present at settlement, failed to persist into later samples.

Community structure varied during the year. Of the 77 possible comparisons between the 13 sampling periods, only 18 displayed similarities in community structure. A full list of similarities is given in Table 4 . Most differences occurred between samples in the settlement season and those within the over-wintering period, although there were exceptions such as the similarity between April and early July, early and late August, and November. The transformed species presence-and-absence composition of the YOY component of the population was significantly different from that of the established non-YOY component at all times.

Settlement was recorded for 21 of the 29 species encountered during the study. Newly settled individuals were detected on only 1 occasion for some species, while others continued to settle over prolonged periods (Table 1). In species subsequently displaying prolonged settlement, gravid female individuals were often present for extended periods (Table 1). Recently settled individuals were detected for some species over $\geq 2$ mo, e.g. Cancer pagurus, Hippolyte variens, Necora puber, Pagurus bernhardus (L.), Pisidia longicornis and Thoralus cranchii (Leach).

Body size at settlement decreased with increasing temperature during larval development (Fig. 3). Although temperature during development was taken as an average daily value for $30 \mathrm{~d}$ prior to settlement for all species, the more rapid moulting of smaller individuals, at higher temperatures, would reduce the moult increment and the duration of larval development. The high temperatures of mid-August also coincided with the recording of the smallest planktonic larvae in this area (Merin 1998). For 4 of the 5 species that occurred in sufficient numbers to calculate mean size at settlement for several temperatures, 
significant reductions in size were observed: Cancer pagurus, Necora puber, Pirimela denticulata (Montagu) and Pisidia longicornis.

Minimum size at settlement and maximum body size before the end of the growing season were determined for 13 of the species sampled (Table 5). Numbers of YOY individuals were too low to determine these sizes accurately for the other 8 species in which settlement was detected. It was not always possible to detect consecutive instars due to mixing of distributions, and so the number of moults from settlement to the cessation of growth before winter was determined for only 5 species. Of the crab species sampled, Necora puber displayed the greatest increase in size, from 1.8 to $19.6 \mathrm{~mm}$ carapace width. The growth of some species was relatively low as they settled later in the season (Table 1), reducing the time available for growth (e.g. Xantho pilipes).

Early seasonal mortality estimates were derived for 5 decapod species in which clear progression through instars could be detected (Fig. 4). It was assumed that no YOY individuals migrated from the study area. In general, these 5 species represented the more abundant species at the site (Table 1). Mortality was higher between instars II \& III for all species, with the exception of Pisidia longicornis. The inter-moult duration between Stages II \& III for $P$. longicornis is short relative to the following inter-moult periods, resulting in higher mortality during Stages III \& IV (Robinson \& Tully 2000a). Of the 5 species, the highest mortality rates were recorded for Cancer pagurus and Necora puber, with a 64 and $67 \%$ reduction in numbers, respectively, between Stages II \& IV. High rates of early mortality were evident in the LFD of these species (Fig. 5). A number of factors prevented the separation of instar groups for other species, including low numbers of individuals (e.g. Pagurus bernhardus, Galathea nexa), early mixing of instar groups due to variable growth (Thoralus cranchii, Hippolyte variens), and late settlement (Xantho pilipes). However, a reduction in numbers of individuals was observed with increasing body size for all species to some extent.

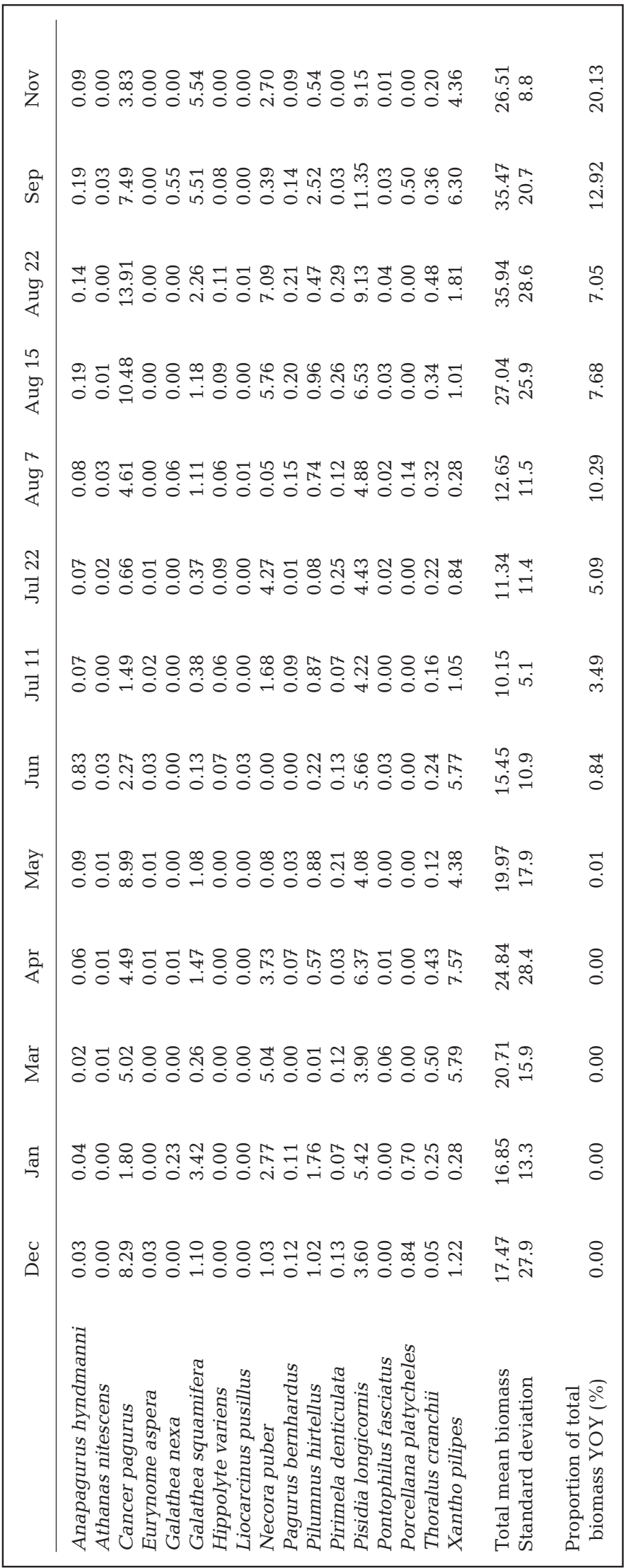




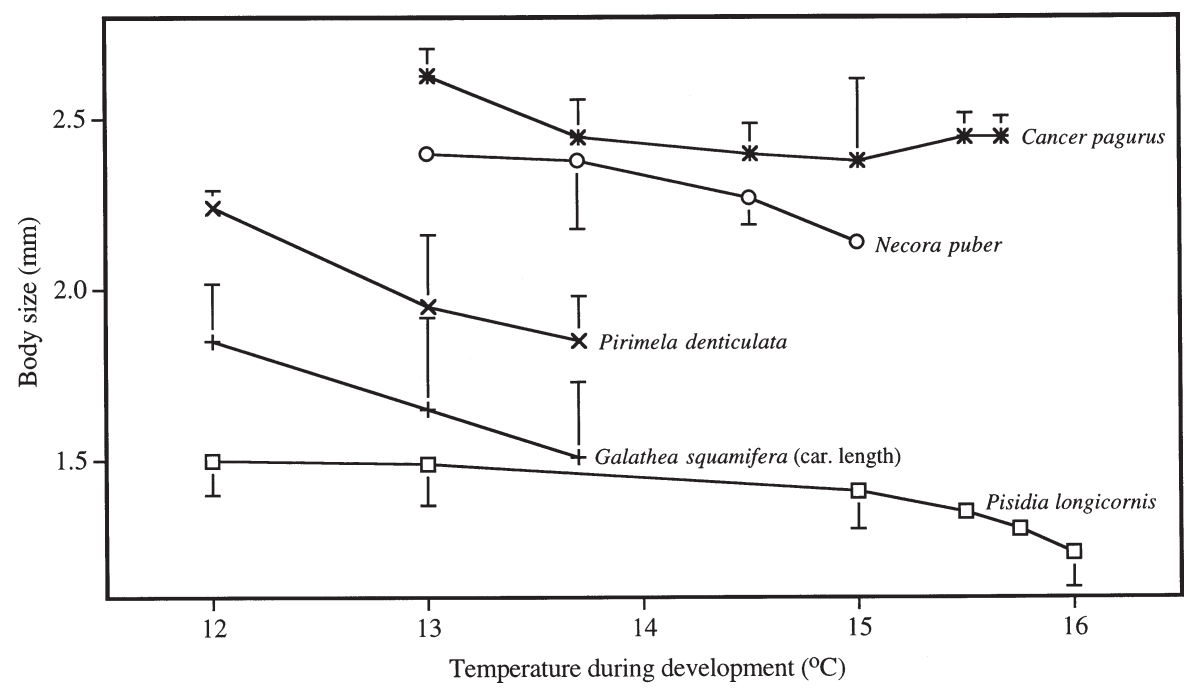

Fig. 3. Relationship between mean $( \pm \mathrm{SD})$ size of first moult instar and mean temperature $\left({ }^{\circ} \mathrm{C}\right)$ for $30 \mathrm{~d}$ prior to settlement in 5 decapod species. All sizes carapace width except for Galathea squamifera (= carapace length)

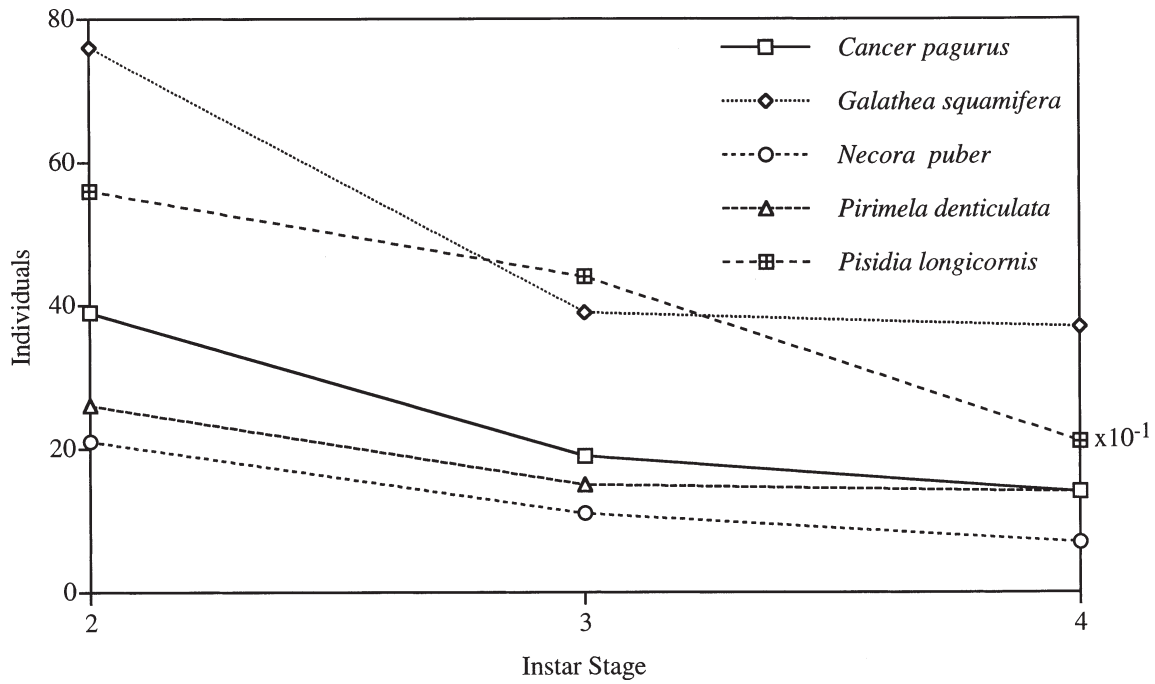

Fig. 4. Decline in numbers of 5 decapod species between the second, third and fourth crab stages, calculated from total number of individuals sampled in each instar, June to November 1997

\section{DISCUSSION}

High densities of decapod species were recorded throughout the study period; some of the species recorded had not previously been described for the study location. It is likely that the majority of species sampled, most of which were relatively small-bodied, settle into and remain within the vicinity of the habitat sampled. For species such as Cancer pagurus, shallow water, cobble nursery habitats probably represent a major source of recruitment to offshore fisheries. It is unclear why some species settle into the area but fail to persist until the end of the season (e.g. Liocarcinus pusillus). Lewis (1991) stated that recruitment failures of barnacles stemmed from planktonic or initial settlement conditions.

Several species that may have been expected in samples were noticeably absent. Although adults are fished in the area, no juvenile lobster Homarus gammarus (L.) were detected. This may be an indication that the habitat requirements of juvenile lobster are not met in the area, and that settlement occurs elsewhere (Howard \& Bennett 1979). Other noticeable absences from the area included Carcinus maenas (L.) and Galathea strigosa (L.). Both these species were recorded in planktonic samples (Merin 1998).

Although trends in abundance and biomass could be seen, the significance of changes was often masked by 
Table 4. Dates on which significant Bray-Curtis similarities in decapod community structure were recorded. Numbers in parentheses: day in month when sampling was conducted

\begin{tabular}{|lll|}
\hline Dec \& Jan & Mar \& Apr & May \& Nov \\
Dec \& Mar & Apr \& Jul (11) & Jul (11) \& Jul (22) \\
Dec \& Apr & Apr \& Aug (15) & Jul (22) \& Aug (7) \\
Dec \& May & Apr \& Aug (22) & Jul (22) \& Aug (15) \\
Jan \& Apr & Apr \& Nov & Jul (22) \& Aug (22) \\
Jan \& Nov & May \& Jun & Aug (15) \& Aug (22) \\
\hline
\end{tabular}

Table 5. Growth potential of decapod species. Caridea growth recorded as increase in weight (g), Paguridea (sl) as shield length $(\mathrm{mm})$ and Galathidea $(\mathrm{cl})$ as carapace length $(\mathrm{mm})$. Increase in carapace width $(\mathrm{mm})$ was recorded for remaining species

\begin{tabular}{|llcc|}
\hline Species & $\begin{array}{c}\text { Min. } \\
\text { size }\end{array}$ & $\begin{array}{c}\text { Max. } \\
\text { size }\end{array}$ & $\begin{array}{c}\text { No. of } \\
\text { moults }\end{array}$ \\
\hline Achaeus cranchii & 1.6 & 2.7 & \\
Anapagurus hyndmanni (sl) & 0.7 & 1.8 & \\
Cancer pagurus & 2.3 & 8.8 & 5 to 6 \\
Galathea squamifera (cl) & 1.2 & 9.5 & \\
Hippolyte variens (g) & 0.002 & 0.05 & \\
Necora puber & 1.8 & 19.6 & 8 to 10 \\
Pagurus bernhardus (sl) & 1.1 & 4.0 & \\
Pilumnus hirtellus & 1.3 & 8.4 & \\
Pirimela denticulata & 1.7 & 6.7 & 5 to 6 \\
Pisidia longicornis & 1.3 & 4.7 & 5 \\
Pontophilus fasciatus (g) & 0.002 & 0.05 & \\
Thoralus cranchii (g) & 0.001 & 0.08 & 1 \\
Xantho pilipes & 1.8 & 3.6 & \\
& & & \\
\hline
\end{tabular}

high variance between sampling-date replicates. Grant (1991) stated that the use of random samples in the presence of high heterogeneity can lead to large sampling variances which can make year-to-year differences difficult to detect (Bowman \& Lewis 1977). It is likely that small-scale patchiness within the habitat sampled caused similar difficulties within the seasonal data set presented here. In an experiment parallel to the present study, significant differences occurred in decapod abundance and community structure between habitats with varying degrees of complexity (Robinson \& Tully 2000b). Identifying the factors that cause seasonal spatial variation in settlement, recruitment and community structure, both temporally and spatially, will allow a more detailed understanding of annual fluctuations and population dynamics.

By the end of the settlement season, YOY individuals were numerically dominant, due to both heavy settlement and decline in non-YOY numbers. The reduction in non-YOY numbers was due mainly to the mortality of short-lived individuals such as Pisidia longicornis soon after reproduction (Robinson \& Tully 2000a). Grant (1991) stated that the small individual body size of YOY specimens suggested that their contribution to total biomass, and presumably their influence on other species and the environment, was of small importance. However, there is probably a high level of interaction between individuals within the YOY component itself, especially when individuals settling later in the season encounter earlier settlers (Moksnes et al. 1997, 1998).

The availability of information relating to the development rate of early benthic phase decapods is limited. It was possible to detect successive instars in a number of the species sampled in this study, and derive crude estimates of growth potential and mortality. These estimates could be substantially improved with knowl-
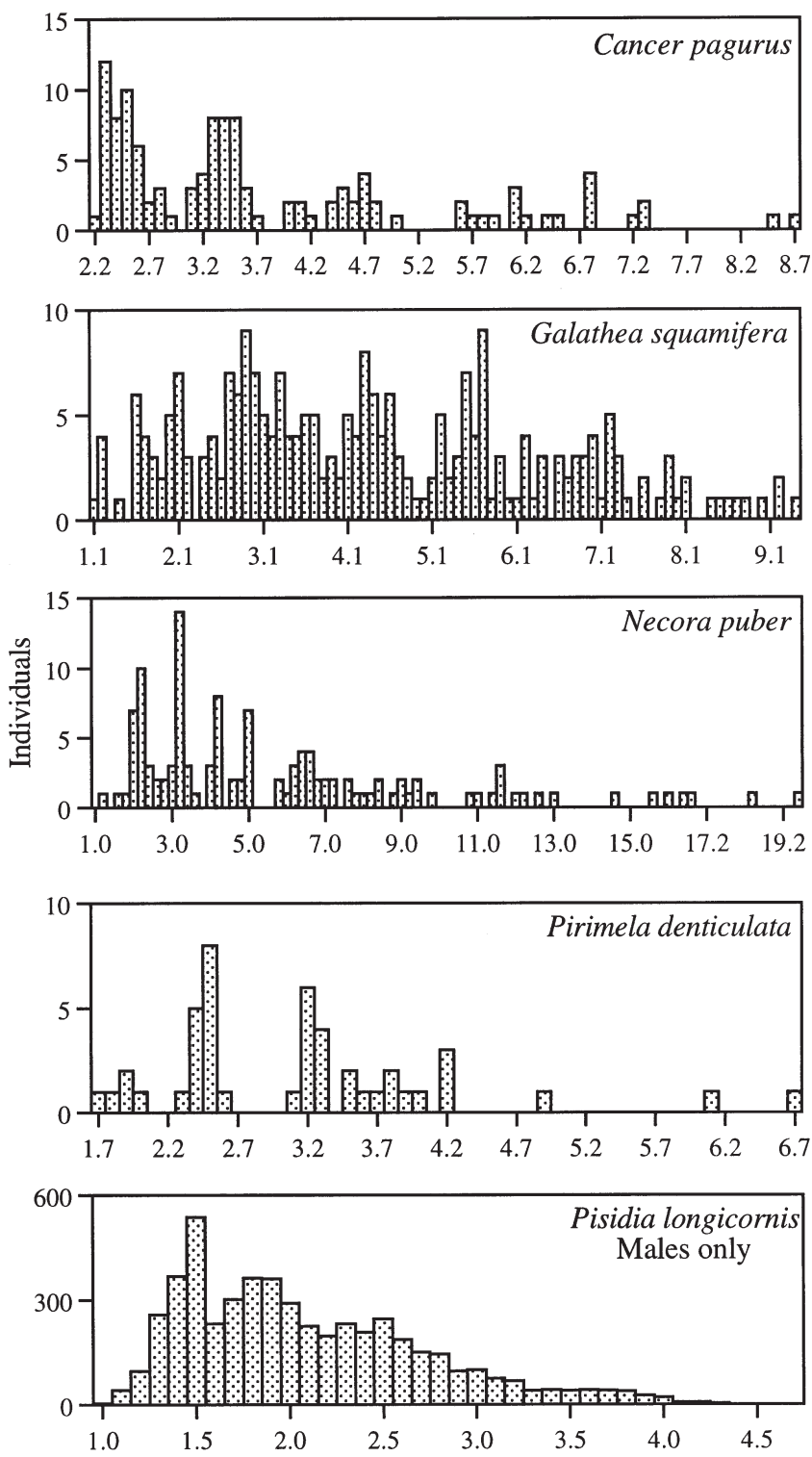

Body size (mm) (carapace width except G.s. carapace length)

Fig. 5. Length-frequency distributions of young-of-the-year cohort of 5 decapod species, June to November 1997 
edge of development rate. Instar duration, body size and activity are closely linked to environmental temperature, and different growth and mortality rates may thus be displayed by individuals settling at different times of the year. Survival may be directly related to size at settlement, with smaller size predisposing individuals to higher rates of mortality (Robinson \& Tully 2000a). Although temperature during larval development would appear to influence body size at settlement, other factors not considered in the present study, such as food availability or the variation in the body size of the spawning stock, may also elicit significant effects. Decreasing body size with increasing temperature during development has been recorded previously for marine copepods (McLaren 1963, McLaren \& Corkett 1980). The numbers of individuals of many of the species sampled during this study were too low at individual sampling times to warrant application of a time scale to growth and mortality estimates. More refined mortality estimates and seasonalised growth curves were derived for Pisidia longicornis (Robinson \& Tully 2000a).

If the magnitude of adult biomass and abundance are presumed to exert a greater influence on the community and environment than the small-bodied YOY component does (Grant 1991), then seasonal minima in these adult parameters may be the most suitable time to release juvenile Homarus gammarus for stockenhancement purposes. In this enhancement method, hatchery-reared juvenile lobster are grown on to later stages of development (Mercer \& Brown 1994) and then released into a fishery catchment area (Addison \& Bannister 1994) in an attempt to avoid the high postlarval mortality rates experienced by recently settled larvae. Some doubt remains as to the subsequent fate of these lobsters, and the numbers that survive to recruit to the fishery (Walker 1986, Bannister et al. 1994, Bannister \& Addison 1998).

Novel information pertaining to the early life-history stages of numerous decapod species was gathered during the study using suction sampling methods. Although no implications are made regarding the interactions between species, conspecifics or the community as a whole, further laboratory and field experimentation could be conducted using seasonal data as a baseline. Examination of the interactions between YOY individuals, YOY and non-YOY individuals, and between the decapod assemblage and the environment will enhance understanding of decapod early life history and ecology in this geographically widespread community. Increasing knowledge of seasonal variations, and any patterns that may be associated with these fluctuations, will help to further development of methods for prediction of annual variations in settlement and recruitment.
Acknowledgements. M.R. was funded by the IRAM Scholars Program, BIM Dublin and a scholarship award from Trinity College Dublin.

\section{LITERATURE CITED}

Addison JT, Bannister CA (1994) Re-stocking and enhancement of clawed lobster stocks: a review. Crustaceana 67: 131-155

Bannister CA, Addison JT (1998) Enhancing lobster stocks: a review of recent European methods, results, and future prospects. Bull Mar Sci 62:369-387

Bannister CA, Addison JT, Lovewell SRJ (1994) Growth, movement recapture rate and survival of hatchery-reared lobsters (Homarus gammarus (Linnaeus, 1758)) released into the wild on the English East Coast. Crustaceana 67: 156-172

Bowman RS, Lewis JR (1977) Annual fluctuations in the recruitment of Patella vulgata (L.). J Mar Biol Assoc UK 57: 793-815

Castro M (1995) Use of length-frequency analysis for estimating the age structure of the catch of Nephrops norvegicus (Crustacea: Nephropidae). In: Aiken DE, Waddy SL, Conan G (eds) Shellfish life histories and shellfishery models. International Council for the Exploration of the Sea, Marine Science Symposium, Moncton, New Brunswick, 25-29 June 1990. Page Bros, Norwich, p 301-309

Clarke KR, Warwick RM (1994) Change in marine communities: an approach to statistical analysis and interpretation. Bourne Press Limited, Bournemouth

Cobb JS, Wahle RA (1994) Early life history and recruitment processes of clawed lobsters. Crustaceana 67:1-25

Connell SD, Jones GP (1991) The influence of habitat complexity on postrecruitment processes in a temperate reef fish population. J Exp Mar Biol Ecol 151:271-294

Eckman JE (1983) Hydrodynamic processes affecting benthic recruitment. Limnol Oceanogr 28:241-257

Eggleston DB, Armstrong DA (1995) Pre- and post-settlement determinants of estuarine Dungeness crab recruitment. Ecol Monogr 65:193-216

González-Sanjurjo R (1982) Estudio de la epifauna de la semilla del mejillón en la Ría de Arousa. Boln Inst Esp Oceanogr 7:49-71

Gosselin LA, Qian PY (1997) Juvenile mortality in benthic marine invertebrates. Mar Ecol Prog Ser 146:265-282

Grant A (1991) Population biology and monitoring on rocky shores: some observations on the COST 647 approach. In: Keegan BF (ed) Space and time series data analysis in coastal benthic ecology. Commission of the European Communities, Brussels, p 481-500

Healy B, McGrath D (1988) Marine fauna of Co. Wexford-10. The Crustacea Decapoda of intertidal and brackish water habitats. Ir Nat J 22:470-473

Hobbs RC, Botsford LW, Thomas A (1992) Influence of hydrographic conditions and wind forcing on the distribution and abundance of Dungeness crab, Cancer magister, larvae. Can J Fish Aquat Sci 49:1379-1388

Howard AE, Bennett DB (1979) The substrate preference and burrowing behaviour of juvenile lobsters (Homarus gammarus (L.)). J Nat Hist 13:433-438

Incze LS, Wahle RA (1991) Recruitment from pelagic to early benthic phase in lobsters Homarus americanus. Mar Ecol Prog Ser 79:77-87

Ingle RW (1993) Hermit crabs of the northeastern Atlantic Ocean and Mediterranean Sea. Chapman \& Hall, London 
Ingle RW (1996) Shallow water crabs. Henry Ling Ltd, Dorchester

Kelly KS, Picton BE, Costello MJ (1996) Marine-related papers published in the Irish Naturalists Journal 1925-1994 (CD ROM). Environmental Sciences Unit, Trinity College, Dublin.

Kruskal JB, Wish M (1978) Multidimensional scaling. Sage Publications, Beverly Hills, CA

Lewis JR (1991) Rationale, methods and problems involved in the assessment and causes of recruitment fluctuations of some rocky shore species. In: Keegan BF (ed) Space and time series data analysis in coastal benthic ecology. Commission of the European Communities, Brussels, p 439-480

MacDonald PDM, Green PEJ (1988) User's guide to program MIX: an interactive program for fitting mixtures of distributions. Ichthus Data Systems, Hamilton, Ontario

McConnaughey RA, Armstrong DA, Hickey BM, Gunderson DR (1992) Juvenile Dungeness crab (Cancer magister) recruitment variability and oceanic transport during the pelagic larval phase. Can J Fish Aquat Sci 49:2028-2044

McLaren IA (1963) Effects of temperature on growth of zooplankton, and the adaptive value of vertical migration. J Fish Res Board Can 20:685-727

McLaren IA, Corkett CJ (1980) Temperature-dependent growth and production by a marine copepod. Can J Fish Aquat Sci 38:77-83

Mercer J, Brown R (1994) Lobster stock enhancement in Ireland. Aquaculture Ireland, April/May 1994:20-23

Merin L (1998) Seasonal patterns of larval production and its relationship to settlement and recruitment to the benthos in a decapod community in the Saltee Islands, Co. Wexford, Ireland. MSc thesis, Trinity College, Dublin

Moksnes PO, Lipcius RN, van Montfrans J (1997) Cannibalprey dynamics in young juveniles and postlarvae of the blue crab. J Exp Mar Biol Ecol 215:157-187

Moksnes PO, Pihl J, van Montfrans J (1998) Predation on postlarvae and juveniles of the shore crab Carcinus maenas: importance of shelter, size and cannibalism. Mar Ecol Prog Ser 166:211-225

Olmi EJ III, Lipcius RN (1991) Predation on postlarvae of the blue crab Callinectes sapidus Rathbun by sand shrimp Crangon septemspinosa Say and grass shrimp Palaemonetes pugio Holthius. J Exp Mar Biol Ecol 151:169-183

Perkins-Visser E, Wolcott TG, Wolcott DL (1996) Nursery role of seagrass beds: enhanced growth of juvenile blue crabs (Callinectes sapidus Rathbun). J Exp Mar Biol Ecol 198: 155-173

Phillips BF (1990) Estimating the density and mortality of

Editorial responsibility: Otto Kinne (Editor),

Oldendorf/Luhe, Germany juvenile western rock lobster (Panulirus cygnus) in nursery reefs. Can J Fish Aquat Sci 47:1330-1338

Phillips BF, Brown RS (1989) The West Australian rock lobster fishery: research for management. In: Caddy JF (ed) Marine invertebrate fisheries: their assessment and management. John Wiley \& Sons, Chichester, p 159-181

Pile AJ, Lipcius RN, van Montfrans J, Orth RJ (1996) Densitydependant settler-recruit-juvenile relationships in blue crabs. Ecol Monogr 66:277-300

Robinson M, Tully O (2000a) Dynamics of a sub-tidal population of Pisidia longicornis. J Mar Biol Assoc UK 80:75-83

Robinson M, Tully O (2000b) Spatial variability in decapod community structure and recruitment in sub-tidal habitats. Mar Ecol Prog Ser 194:133-141

Roughgarden J, Gaines S, Possingham H (1988) Recruitment dynamics in complex life cycles. Science 241:1460-1466

Smaldon G (1972) Population structure and breeding biology of Pisidia longicornis and Porcellana platycheles. Mar Biol 17:171-179

Smaldon G (1993) Coastal shrimps and prawns. Henry Ling Ltd, Dorchester

Valdes LJ, Alvarez Osorio T (1983) Datos preliminaries sobre el desarrollo larvario de Macropipus puber (Linnaeus, 1767) y Pisidia longicornis (Linnaeus, 1767) en condiciones de laboratorio. Infmes Téc Inst Esp Oceanogr 16: $1-18$

Wahle RA, Incze LS (1997) Pre- and post-settlement processes in recruitment of the American lobster. J Exp Mar Biol Ecol 217:179-207

Wahle RA, Steneck RS (1992) Habitat restrictions in early benthic life: experiments on habitat selection and in situ predation with the American lobster. J Exp Mar Biol Ecol 157:91-114

Walker RS (1986) The first returns of tagged juvenile lobsters (Homarus gammarus (L.)) after release to the wild. Aquaculture 52:231-233

Warwick RM, Clarke KR, Gee JM (1990) The effects of disturbance by soldier crabs Mictyris platycheles H. Milne Edwards on meiobenthic community structure. J Exp Mar Biol Ecol 135:19-33

White RG, Hill AE, Jones DA (1988) Distribution of Nephrops norvegicus (L.) larvae in the western Irish Sea: an example of advective control on recruitment. J Plankton Res 10: $735-747$

Young EF, Bigg GR, Grant A, Walker P, Brown J (1998) A modelling study of environmental influences on bivalve settlement in The Wash, England. Mar Ecol Prog Ser 172: $197-214$

Submitted: October 11, 1999; Accepted: March 28, 2000

Proofs received from author(s): October 25, 2000 